\title{
Phytoprotection
}

\section{John Dearness (1852-1954) : Canadian pioneer mycologist-plant pathologist}

\section{R.H. Estey}

Volume 74, numéro 3, 1993

URI : https://id.erudit.org/iderudit/706042ar

DOI : https://doi.org/10.7202/706042ar

Aller au sommaire du numéro

\section{Éditeur(s)}

Société de protection des plantes du Québec (SPPQ)l

\section{ISSN}

0031-9511 (imprimé)

1710-1603 (numérique)

Découvrir la revue

Citer cet article

Estey, R. (1993). John Dearness (1852-1954) : Canadian pioneer mycologist-plant pathologist. Phytoprotection, 74(3), 135-141. https://doi.org/10.7202/706042ar
Résumé de l'article

John Dearness, un enseignant doué d'un professionalisme remarquable, fut le premier mycologue canadien reconnu internationalement, en plus d'être un pionnier autodidacte en phytopathologie. Ses habiletés à isoler et à identifier les champignons phytoparasites et son empressement à assister des phytopathologistes professionnels étaient tellement reconnus qu'il fut élu président de la division canadienne de l'American Phytopathological Society. La Société canadienne de phytopathologie, dont il fut un membre-fondateur, l'a nommé membre honoraire. Plusieurs autres honneurs lui ont été décernés en reconnaissance de sa contribution à la botanique, à la mycologie et à la phytopathologie au Canada. 


\title{
John Dearness (1852-1954): Canadian pioneer mycologist-plant pathologist
}

\author{
Ralph H. Estey ${ }^{1}$ \\ Received 1993-05-25; accepted 1993-08-24
}

John Dearness, a professional educator who became the first internationally acknowledged Canadian-born mycologist, was also a largely self-taught pioneer plant pathologist. His ability to isolate and identify plant parasitic fungi, and his readiness to assist professional plant pathologists, became so widely known that he was elected President of the Canadian Division of the American Phytopathological Society. The Canadian Phytopathological Society, of which he was a charter member, made him an honorary member. Many more honors were conferred on this remarkable man in recognition of his contributions to botany, mycology, and plant pathology in Canada.

\section{Estey, R.H. 1993. John Dearness (1852-1954): pionnier canadien en mycologie et en phytopathologie. PHYTOPROTECTION 74: 135-141.}

John Dearness, un enseignant doué d'un professionalisme remarquable, fut le premier mycologue canadien reconnu internationalement, en plus d'être un pionnier autodidacte en phytopathologie. Ses habiletés à isoler et à identifier les champignons phytoparasites et son empressement à assister des phytopathologistes professionnels étaient tellement reconnus qu'il fut élu président de la division canadienne de l'American Phytopathological Society. La Société canadienne de phytopathologie, dont il fut un membre-fondateur, l'a nommé membre honoraire. Plusieurs autres honneurs lui ont été décernés en reconnaissance de sa contribution à la botanique, à la mycologie et à la phytopathologie au Canada.

In the 1930s, John Dearness, of London, Ontario, was so well known as a mycologist that he was elected, in 1937, President of the Mycological Society of America, becoming the first Canadian mycologist to be internationally acknowledged. His contributions to North American mycology have been reviewed by others (Ginns 1986; Parmelee 1978; Rogers 1981), but his achievements as a noteworthy plant pathologist are not so well known. This paper therefore will emphasize his activities and interests pertaining to plant pathology.

1. Department of Plant Science, Macdonald Campus of McGill University, Sainte-Annede-Bellevue, Québec, Canada H9X 3V9
Born in Hamilton, Ontario on 13 May 1852 , of parents who had come to Canada from the Orkney Islands, young Dearness spent much of his youthful years on farms near St. Marys, Ontario. It was there that he acquired a love of nature that lasted throughout his long life of 102 years.

\section{EDUCATION}

His primary education was obtained in local schools. In 1869 Dearness passed an examination that qualified him to teach in the public schools (Judd 1979). He began his teaching career at the age of seventeen in a one-room log schoolhouse. At 18 he attended the Toronto Normal School where he distinguished 


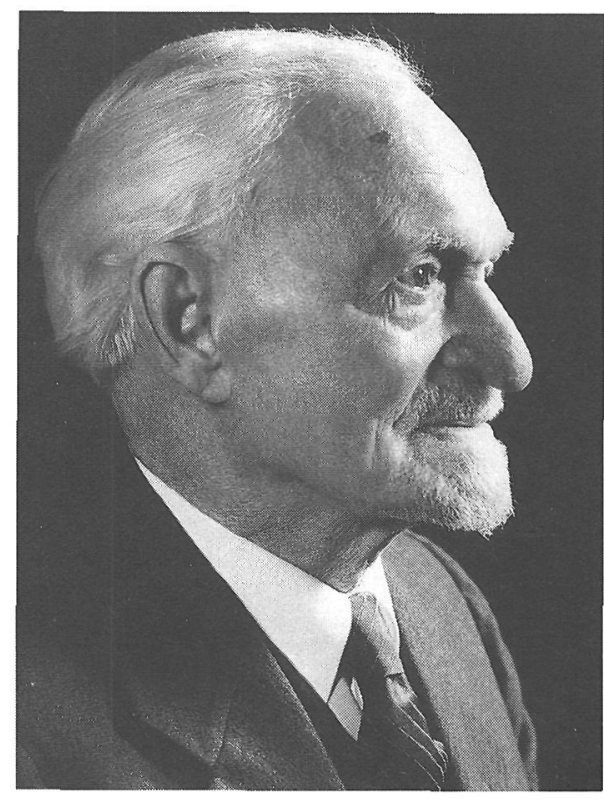

John Dearness (1852-1954)

himself as a teacher-trainee and won a special certificate in "Natural History, Botany and Agricultural Chemistry." He graduated in 1871, with the highest honors and a teacher's certificate. Later that year he became Principal of the school in the village of Lucan, Ontario. Two years later he was made Principal of a larger school in Strathroy, Ontario. Recognizing his ability as a teacher-administrator, the educational authorities made Dearness a Public School Inspector for East Middlesex county in 1874 , a position which he held for $25 \mathrm{yr}$ (Talman 1957).

For a few years Dearness held at least two positions. In addition to being Inspector of Schools from 1874 to 1899, he was Professor of Botany and Zoology in the Medical School of Western University (now the University of Western Ontario) from 1888 to 1914. The Arts Calendar of Western shows that he was also a Lecturer in Botany in the Arts Faculty for a similar period. Dearness resigned from his position as Inspector of Public Schools in 1899, to become Vice-Principal of the London Normal School. He became Principal in 1918. In the meantime his interest in nature study, especially botany and the fungi that incite plant diseases, had become widely known and he was appointed Examiner in Botany for the University of Toronto in 1900 (Anonymous 1900).

The remarkable feature of Dearness' life at that time is that he held such high positions in the world of science and education without having any formal University education or degrees. In 1902 he earned his first degree, a B.A., from the University of Western Ontario, when he was $50 \mathrm{yr}$ old. He was awarded a M.A. by that university the following year.

\section{SCIENTIFIC INTERESTS}

While he was a school inspector, Dearness took time to delve more deeply into his favorite avocation, that of nature study. He became a largely self-taught naturalist with a special regard for the fungi and their relationships to plants, and thus to phytopathology.

\section{Plant diseases}

His early interest in plant diseases is seen in the minutes of the Microscopical Section of the Entomological Society of Ontario, London, of which he was a founding member. It is recorded that Dearness gave a lecture-demonstration of the fungal nature of the black knot disease of stone fruits during the meetings of 23 and 24 January 1891. One of the members of that group was William Saunders who had been experimenting with a lime and sulphur solution for the control of plant pests. Saunders gave Dearness a bottle of that solution for experiments on the control of the black knot disease (Dearness 1939).

Later in 1891, Dearness visited Manitoba where he collected stem rust of wheat, and Didymosphaeria manitobiensis E. \& $E$. When the latter fungus was named and described by Ellis and Everhart, it became the earliest published record of a Manitoba fungus (Bisby et al. 1929).

On 27 November 1891, Dearness took charge of the meeting of the Microscopical Section and gave a talk on the nature and habits of the group of plant parasitic fungi known as powdery mildews. The members, aided by large diagrams provided by Dearness, examined leaves infected with species of Uncinula and 
Phyllactinia. During the following meeting they examined and identified six more powdery mildews, with guidance from Dearness. In December, his topic was again fungi that infect plants and produce leaf diseases. Two years later Dearness was elected Chairman of the Microscopical Section, the members of which appear to have been as interested in microscopic fungi as in insects. The minutes of many of their meetings tell of the fungi and fungus-infected plants they examined, under the supervision of Dearness.

Dearness was also a leader in the Botanical Section of the Entomological Society, having been elected Chairman at its first meeting on 3 May 1890 (Judd 1979). It was his interest in botany that prompted him to ask James Fletcher, Dominion Entomologist and Botanist, how much he might have to pay for a copy of Flora Americae, a book published by Frederick Pursch in 1814. Fletcher's reply, in a letter dated 22 November 1892 that is in the National Archives in Ottawa, includes this comment: "Pursh's Flora is now a rare book and would be useful, but I am really doubtful whether it is worth paying $\$ 2.50$ for it...". Such a statement is not only a commentary on their respective interests, but also on their financial status and on the 1892 value of the dollar.

\section{PLANT RUSTS}

While studying the powdery mildew fungi on leaves, Dearness became interested in the fungi that cause rust diseases in plants. He is said to have made the first report on the wheat rust, Puccinia graminis Pers., in Canada (Judd 1979). The first volume of the journal Erythea, published in December 1893, has the names of five species of Puccinia, and one of Uromyces, named by Dearness and his friend and long-time collaborator, Homer D. House, of the New York Botanic Garden. J.C. Arthur, in his 1934 book Manual of the rusts in United States and Canada, lists no fewer than 20 rust fungi that were originally named by Dearness and House (Arthur 1934). When he was 88 years old, Dearness was still collaborating with House in naming new and noteworthy species of New York fungi. Their 1940 list included Phyllosticta dearnessii D. \& H., a leaf parasite that had obviously been named in honor of Dearness, and four other plant parasitic species, plus an epiparasite on the black knot fungus Dibotryon morbosum (Schw.) Theiss and Syd. (Dearness and House 1940).

In November 1894, Dearness was elected vice-president of the Entomological Society of Ontario. He became President the following year and held that office for $2 \mathrm{yr}$. In his presidential address, delivered 21 October 1896, Dearness commented on "a new and important field, that of artificially controlling insects by vegetable parasitism." This showed that he took an early interest in the biological control of pest organisms. In the published account of his address, nearly three pages are devoted to parasitic fungi. Another remarkable feature of that address was his report of finding nematodes in diseased roots of peas and the comment that he considered them to have been one of the causes of the disease (Dearness 1897). That was at a time when plant parasitic nematodes were virtually unknown to Canadian horticulturists or plant pathologists.

\section{Plant pathology}

It was around this time that Dearness began making notes for a book on the teaching of nature study, which was published in 1905 (Dearness 1905). When the Nova Scotia Department of Education initiated a summer session in nature studies and agriculture, in 1908, they recruited Dearness as guest lecturer and found him to be "one of the most efficient teachers it has ever been our fortune to meet" (Anonymous 1909). Dearness was a member of the American Nature Study Society and his name is in its first directory of members, published in the Nature Study Review for 1909, a publication of which he was an Associate Editor.

Dearness collaborated, or communicated with, many mycologists and plant pathologists in addition to House and Fletcher. His major botanical and mycological correspondents in Europe and North America have been named else- 
where (Parmelee 1978). Among his earliest collaborators was the selftaught American mycologist J.B. Ellis (1829-1905) with whom he named many new species of Canadian fungi. Their first published list included at least one plant pathogen (Ellis and Dearness 1899).

Dearness is reported to have collected oats that were parasitized by a species of Septoria in Ontario in 1915 (Leblond 1942). If the report is correct, Dearness' would be the first record of a Septoria disease of oats in Canada, and possibly in North America (Weber 1922).

Dearness' interest in plant pathology is clearly seen in his report on the fungi collected by the naturalists of the 19131918 Canadian Arctic Expedition. He commented on how surprised he was to see the relatively small number of summer stages of parasitic fungi and the wide range of host plants inhabited by one species (Dearness 1923).

In 1916 Dearness began a series of papers in Mycologia, on "New or noteworthy species of fungi," which continued, intermittently until 1929. Although a number of his so-called new species of fungi were plant parasites, it was not until the 1920s that his interest in plant pathology was clearly expressed. That was mostly after his compulsory retirement because of age from the principalship of the London Normal School in 1922.

In 1926, his fourth list of new and noteworthy fungi included 17 species that were plant parasites (Dearness 1926a). His fifth list, published two years later, included 16 parasitic species or varieties on named hosts, each of which was accompanied by a comment on the disease symptoms induced by that fungus. In 1929, he published a sixth list which gave English-only diagnoses of 24 Hyphomycetes, six or more of which were of phytopathological interest (Dearness 1929a).

The "Rostrup" of Canada

B.T. Dickson, Professor of Plant Pathology at McGill University's Faculty of Agriculture, acknowledged the cooperation of Dearness in his studies on mosaic diseases of plants (Dickson 1922).
Dickson was so impressed by the plant pathological activities of Dearness that he referred to him as the "Rostrup of Canada" (Dickson 1925). That was highly complimentary, because the legendary Emil Rostrup (1831-1907) in Denmark, had occupied the first chair of plant pathology in the world, and was widely acclaimed for his work as a plant pathologist-mycologist.

In 1925 Dearness referred to "physianship to plants" as being "almost the youngest of professions" (Dearness 1925a). Members of that profession in Canada recognized his accomplishments in their general field of activities by making him President of the Canadian Division of the American Phytopathological Society in 1926 (Tamblyn 1955).

The central topic of his presidential address was fungus diseases of the flower garden. During that presentation, Dearness named 25 species of diseaseinducing fungi and commented on the severity of the infection on each species (Dearness 1926c).

In an appendix to the 1926 report on the prevalence of plant diseases in Canada, Dearness named 343 species of fungi in five genera, and gave the mean spore measurements of each. He was of the opinion that "the Anthracnoses come next to the rusts and smuts in importance as producers of plant diseases." As if to emphasize this, the title of his paper was given as "An annotated list of Anthracnoses in the open and under glass in Canada and the adjoining United States" (Dearness 1926b). Dearness contributed to the plant disease survey for several years and I.L. Conners, the compiler of the 1931 survey, specifically thanked him for his "unfailing interest and assistance."

When the Canadian Division of the American Phytopathological Society was dissolved and the Canadian Phytopathological Society was organized, in 1929, Dearness joined as one of its charter members. In 1937 he became the first Canadian-born president of the Mycological Society of America. In his presidential address, "The background of mycology and Mycologia," he included 
comments about rust fungi and argued that the biblical statement that "moth and rust doth corrupt" (Matthew 6:19) should be interpreted as a reference to insects and fungi destroying clothing and food (Dearness 1938a).

When plant pathologist G.B. Sanford, of the Dominion Laboratory of Plant Pathology, Edmonton, Alberta, found a destructive root rot of alfalfa and clover in Alberta and Saskatchewan, he turned to Dearness for assistance in determining its cause. When this was done, they jointly published the name of a new species of Plenodomus in 1930 (Dearness and Sanford 1930).

When William R. Foster (1905-1991), an Assistant Plant Pathologist of the British Columbia Department of Agriculture, noticed some deformed loganberries with a fungus growing on their stigmas and anthers, he sent specimens to Dearness for identification and comment. That resulted in the publication of a co-authored paper on anther and stigma blight of loganberry (Dearness and Foster 1933). In 1938 they collaborated in the publication of a paper on a Coniosporium disease of apples and crabapples (Dearness and Foster 1938). In that year also, Dearness published a note on a fungus found on rose leaves (Dearness 1938b).

When J.L. Howatt and S.F. Clarkson were perplexed by what appeared to be a new apple rot that was prevalent in the apple stores of the Dominion Experimental Farm, Fredericton, they appealed to Dearness for help, which they received (Dearness et al. 1936).

\section{Tree diseases}

For several years Dearness focused his attention on diseases of trees. He contributed the section on "Forest and Shade Tree Diseases," in the fifth annual report on the prevalence of plant diseases in Canada (Dearness 1925b). In his 1926 list of new and noteworthy fungi, Dearness described a fungus that he found on blighted needles among the green ones of balsam fir (Dearness 1926a), and his address to members of the Canadian Division of the American Phytopathological Society in December 1928, was titled "Observations on needle blight of white pine" (Dearness 1929b).

By 1930 the reputation of Dearness as a mycologist with a knowledge of the fungi that incite disease in trees and other plants was well known throughout Canada and the United States. When a fire swept through a forested area of western British Columbia, W.J. Hansbrough collected fungi from 15 species of shrubs and trees and sent them to Dearness for identification. Dearness was particularly interested in the number of Cytospora specimens in the collection, and the fact that most of them appeared to be of one, undescribed, species. They eventually published a paper on that Cytospora outbreak, and described a new species (Dearness and Hansbrough 1934).

Apparently Dearness' interest in tree diseases and the fungal destruction of wood went back to at least 1889 when he discovered a fungus on maple logs. In 1950 , when he was 99 years old, he wrote an account of that early discovery and sent specimens to P.H. Gregory for comparison with more recent findings of a similar or identical fungus (Gregory 1977).

After a fire destroyed the herbarium of the University of Tennessee in 1934, Dearness became interested in the fungi of that State. The list of new species of Tennessee fungi, that he published in 1941, included several plant parasites and the names of their host plants (Dearness 1941).

\section{MANY HONORS}

During the 1941 summer foray of the Mycological Society of America, which was based at Macdonald College, Sainte-Anne-de-Bellevue, Québec, 25 - 28 August, the members spent one afternoon at the Montréal Botanic Garden where they participated in the dedication of the John Dearness Laboratory of Plant Pathology. The ceremony was opened by Father Marie-Victorin who extolled the mycological and phytopathological accomplishments of Dearness, who was then given a key to officially open the laboratory (Snell 1942).

Various other honors and awards were bestowed upon this remarkable 
man. The award in which he took the most pride was an honorary LL.D. conferred on him by the University of Western Ontario on 28 May 1926. In 1935 he was awarded the King George $V$ Jubilee Medal, and in 1936 he was elected a Fellow of the Royal Society of Canada. A more complete listing of his honors, and a list of most of his publications, has been provided by his son-inlaw (Tamblyn 1955), who published at least six articles that eulogized Dearness (Judd 1979).

The city of London, Ontario, made Dearness a Freeman of that City on the occasion of his 90th birthday, in 1942. When the Imperial Order of the Daughters of the Empire, in London, received their charter on 9 May 1945, it was under the name of the Dr. John Dearness Chapter, and when he was 101 years old, in 1953, the John Dearness Home for Senior Citizens in London was named in his honor. It was only after he was 100 years old, when his hearing and his eyesight deteriorated so much that he could no longer enjoy his hobby as an active naturalist, that John Dearness welcomed the death that came to him on 6 December 1954.

\section{ACKNOWLEDGMENT}

The photo of John Dearness is a courtesy of the Regional Collection of the D.B. Weldon Library, University of Western Ontario.

\section{REFERENCES}

Anonymous. 1900. University of Toronto calendar for 1900.

Anonymous. 1909. Annual report of the Secretary for Agriculture (Nova Scotia) for 1908 (1909). p. 21.

Arthur, J.C. 1934. Manual of the rusts of United States and Canada. Purdue Research Foundation. Lafayette, Indiana. 434 pp.

Bisby, G.R., A.H.R. Buller, and J. Dearness. 1929. The fungi of Manitoba. Longmans, Green and Company. London, England. 194 pp.

Dearness, J. 1897. Annual address of the President. Annu. Rep. Entomol. Soc. Ont. 27: 2-30.
Dearness, J. 1905. The nature study course, with suggestions for teaching it based on notes and lectures of teachers in training. The Copp, Clark Company Ltd. Toronto, Ontario. $206 \mathrm{pp}$.

Dearness, J. 1923. Report of the Canadian Arctic expedition 1913-18. Volume IV. Botany, Part C: Fungi. 24 pp.

Dearness, J. 1925a. A Mycologist at large. Phytopathology 15: 301 (Abstract).

Dearness, J. 1925b. Forest and shade tree diseases. Pages 61-68 in Fifth Annual Report on the Prevalence of Plant Diseases in Canada. Experimental Farms Branch, Dom. Dep. Agric. Ottawa, Ontario. 93 pp.

Dearness, J. 1926a. New and noteworthy fungi IV. Mycologia 18: 236-255.

Dearness, J. 1926b. An annoted list of Anthracnoses in the open and under glass in Canada and the adjoining United States. Dom. Dep. Agric. Div. Bot., Bull. 71, Appendix I. pp. 62-76.

Dearness, J. 1926c. Some fungus foes of the flower garden. A locality list with notes. Phytopathology 16: 756-757.

Dearness, J. 1929a. New and noteworthy fungi VI. Mycologia 21: 326-332.

Dearness, J. 1929b. Observations on needle blight of white pine. Phytopathology 19: 413 (Title only).

Dearness, J. 1938a. The background of mycology and Mycologia. Mycologia 30: 111119.

Dearness, J. 1938b. Sphaceloma rosarum as Gloeosporium rosaecola. Mycologia 30: 561-562.

Dearness, J. 1939. Reminiscences of the Early Days of the Society. Can. Entomol. 71: 2124.

Dearness, J. 1941. New species of Tennessee fungi. Mycologia 33: 360-366.

Dearness, J., and W.R. Foster. 1933. Anther and stigma blight of loganberry. Can. J. Res. 9: 43.

Dearness, J., and W.R. Foster. 1938. Coniosporium disease of apples and crab-apples. Can. J. Res. Sect. C Bot. Sci. 16: 274-276.

Dearness, J., and J.R. Hansbrough. 1934. Cytospora infection following fire injury in western British Columbia. Can. J. Res. Sect. C Bot. Sci. 10: 125-128.

Dearness, J., and H.D. House. 1940. New and noteworthy species of New York fungi. N.Y. State Mus. Circ. 24: 25-60.

Dearness, J., and G.B. Sanford. 1930. A new species of Plenodomus. Ann. Mycol. 28: 324-325.

Dearness, J., J.L. Howatt, and S.F. Clarkson. 1936. A new disease of apples caused by Dasycarpoma allantoideum (Peck) Dearness. Proc. Can. Phytopathol. Soc. 6: 10. 
Dickson, B.T. 1922. Studies concerning mosaic diseases. Macdonald College Tech. Bull. No. 2. 27 pp.

Dickson, B.T. 1925. Plant pathology in Canada. Sci. Agric. 5: 211-217.

Ellis, J.B., and J. Dearness. 1899. New species of Canadian fungi. Trans. Can. Inst. 6: 637640.

Ginns, J. 1986. The Canadians John Macoun and John Dearness, and their contributions to North American mycology. Mycotaxon 26: 47-53.

Gregory, P.H. 1977. Spores in air. Annu. Rev. Phytopathol. 15: 1-11.

Judd, W. 1979. Early naturalists and natural history societies of London, Ontario. Phelps Publishing Co. London, Ontario. 215 pp.
Leblond, D. 1942. Studies on speckled leaf blotch of oats (Septoria avenae Frank). M.Sc. Thesis, McGill University. 56 pp.

Parmelee, J.A. 1978. The Dearness mycological collection. Mycologia 70: 509-526.

Rogers, D.P. 1981. A brief history of mycology in North America. Harvard University Printing Office. Cambridge, Mass. 86 pp.

Snell, W. H. 1942. Report on the 1941 foray. Mycologia 34: 350-353.

Talman, J.J. 1957. John Dearness 1852-1954. Proc. Trans. R. Soc. Can. 51: 79-83.

Tamblyn, W.F. 1955. John Dearness. Mycologia 47: 909-915.

Weber, G.F. 1922. Septoria diseases of cereals. Phytopathology 12: 449-471. 